\title{
Apresentação ao número 36
}

\author{
Elena Vássina \\ Álvaro Faleiros \\ Mariângela de Araújo
}

\section{John Milton}

É um prazer apresentar ao nosso leitor esta edição N. 36 da TradTerm Revista de Tradução e Terminologia, que reúne trabalhos de docentes e pesquisadores dos diferentes centros acadêmicos que se dedicam aos estudos nesses campos do saber. Primeiramente, gostaríamos de destacar a ampla diversidade geográfica da filiação institucional dos autores deste número: contamos com artigos elaborados por pesquisadores das seguintes universidades: Universidade Federal do Maranhão, Universidade Federal do Rio Grande do Norte, Universidade Estadual do Ceará, Universidade Federal de Pernambuco, Universidade de Brasília, Universidade de São Paulo, Universidade Federal de Santa Catarina e Universidade Federal do Rio Grande do Sul. Observando essa variedade geográfica, pode-se notar o vigor e crescente interesse acadêmico pelos estudos de tradução e terminologia. Acreditamos que, além de cumprir seus objetivos de mostrar as atuais perspectivas nas pesquisas destas áreas do saber, este novo volume da revista poderia também estimular novos e frutíferos debates acerca da temática apresentada nos sete artigos publicados.

A rigorosa seleção, realizada por competentes pareceristas do Conselho Editorial e também ad hoc, ao garantir seriedade e imparcialidade na escolha de publicações, permite à revista TradTerm continuar a ser referência importante na área dos estudos de tradução e terminologia. 
Iniciamos a apresentação do volume com um artigo intitulado "Traduções do feminino em "Persuasion", de Jane Austen", redigido pelos pesquisadores Marcela Aparecida Silvestre e Jonathan Gustavo Pessoa Cavalcanti de Lima, da Universidade Federal do Rio Grande do Norte. Partindo do pressuposto de que estudos recentes indicam que o conceito de tradução tem sido repensado no sentido de se atribuir ao ato tradutório uma dimensão artística e subjetiva, os autores defendem que, com isso, a questão da obrigação de fidelidade ao texto original, que, por muito tempo foi central nas discussões sobre a boa qualidade das traduções, é colocada em suspeição. Os Estudos da Tradução manifestam um interesse crescente sobre o papel cultural do texto traduzido e da figura do tradutor na sociedade. A associação dos Estudos da Tradução com a Crítica Literária Feminista busca detectar e comparar como os tradutores lidam com as ocorrências presentes no textofonte e a sua recriação no texto traduzido. Com base nos aspectos teóricos apontados, a presente pesquisa propõe uma análise descritiva e comparativa entre a obra Persuasion (1818), da escritora inglesa Jane Austen, e duas traduções para o português brasileiro, produzidas por Celina Portocarrero (L\&PM, 2017) e Roberto Leal Ferreira (Martin Claret, 2012), observando a importância da interferência do tradutor e de suas concepções socioculturais no processo de produção de sentido dos textos traduzidos.

No foco do segundo artigo, intitulado "Aspectos do verso e sua crise nas retraduções brasileiras de "Un coup de dés", de Stéphane Mallarmé", elaborado por Henrique Provinzano Amaral, da Universidade de São Paulo, está a leitura crítica de duas traduções brasileiras do célebre poema mallarmeano "Um lance de dados" [“Un coup de dés”, 1897], assinadas por Haroldo de Campos e Álvaro Faleiros e publicadas pela primeira vez, respectivamente, em 1974 e 2013. Como mote da análise, busca-se retomar aspectos da reflexão de Stéphane Mallarmé em torno da ideia de verso, levando em consideração elementos da história literária e de parte do debate que aquele notável assunto suscitou no século XIX francês. Nesse contexto, ganha relevo especial o texto “Crise de vers", constante do volume mallarmeano das "Divagations" (1897). Por fim, são confrontadas algumas das soluções de tradução adotadas pelos 
tradutores estudados, com o intuito de arrazoar um juízo crítico possível dessas reescritas tradutórias em meio à anterior discussão sobre o verso e sua crise.

As pesquisadoras Janaína Viera Taillade Abud e Vera Lúcia Santiago Araújo analisam questões de audiodescrição no artigo "A relação entre as marcas avaliativas e os elementos narratológicos em um roteiro de audiodescrição para o teatro". Dando continuidade a vários estudos iniciados por Praxedes Filho e Magalhães (2013, 2015), o artigo tem por objetivo analisar se as marcas avaliativas identificadas por meio do Sistema de Avaliatividade (SA), no roteiro de audiodescrição da peça Miralu e a Luneta Encantada, podem ser relacionadas aos elementos narratológicos. Para tanto, é adotada uma metodologia baseada em corpus, utilizando as categorias do SA, até o Segundo nível de delicadeza, assim como as categorias narratológicas baseadas em Jiménez Hurtado (2010) e Pavis (2011, 2015). Como resultado, são encontradas 166 co-ocorrências de marcas avaliativas e elementos narratológicos, entre os quais há $73(43,98 \%)$ associadas a gestos, $42(25,30 \%)$ a figurino e $40(24,10 \%)$ a iluminação. Esses resultados sugerem que essas co-ocorrências podem não ser coincidência, levando em consideração que outros estudos já apontavam a importância de descrições subjetivas em roteiros de audiodescrição.

0 trabalho "O intérprete comunitário: sua agência na entrevista de solicitação de refúgio", da autoria de Fernanda de Deus Garcia e Sabine Gorovitz, que representam a Universidade de Brasília, chama nossa atenção à importância do papel do intérprete comunitário na interação entre o oficial de elegibilidade e o solicitante de refúgio no contexto das entrevistas de solicitação de refúgio no Comitê Nacional para Refugiados (Conare), órgão do Ministério da Justiça brasileiro, responsável pelo deferimento ou não da solicitação de refúgio pelo migrante. Partindo de uma abordagem sociolinguística interacional, as autoras buscam analisar como o intérprete se faz presente durante a entrevista, e de que forma se manifesta linguisticamente. Para conduzir esse estudo, foi realizada pesquisa de campo empírica com observação participante em algumas entrevistas no Conare, além do acesso a diversas gravações dessas interações para a condução das análises. 
Estas revelam estratégias de mediação não apenas linguística, mas também social e cultural por parte do intérprete.

Denise Regina de Sales e Marina Canofre, pesquisadoras da Universidade Federal do Rio Grande do Sul, no artigo intitulado "Conservação dos bens culturais móveis em papel: termos-chave em português e seus equivalentes em russo" visam a descrever e analisar questões de Terminologia e Tradução do par linguístico português-russo relacionadas à pesquisa terminológica "A Linguagem do Patrimônio Cultural Brasileiro: Conservação dos Bens Culturais Móveis". O foco da pesquisa está na descrição de práticas textuais da área, explicitando sua organização conceitual e terminológica, e inclui: a compilação de corpora em português, espanhol, francês, inglês, italiano e russo; a identificação de termos em português; a busca de equivalentes para esses termos nas línguas citadas; e a criação de uma base terminológica on-line multilíngue de acesso gratuito. As investigações baseiam-se nos pressupostos da Teoria Comunicativa da Terminologia (TCT); na noção de equivalência tradutória de Hurtado Albir; nos preceitos metodológicos da Linguística de Corpus; e em trabalhos anteriores do Projeto Terminológico Cone Sul (Termisul).

0 artigo "Audiodescrição fílmica no contexto da formação de tradutores" é elaborado por Arlene Koglin e Vitória Tassara, da Universidade Federal de Pernambuco e da Universidade Federal de Santa Catarina, respectivamente. As autoras analisam os desafios encontrados na aplicação prática das diretrizes de audiodescrição brasileira (Minc, 2010) e norteamericanas (2007/2008) no contexto de formação de tradutores. A partir de um estudo de caso, as autoras refletem acerca do processo didático de audiodescrição do curta-metragem "Mariza". A partir do relato dos aprendizes, observa-se como desafios centrais a seleção de informação prioritária, a impossibilidade de neutralidade nas escolhas e a subjetividade de algumas diretrizes.

Para finalizar a presente edição da TradTerm, Luis Henrique Serra, da Universidade Federal do Maranhão, e Mariângela de Araújo, da Universidade São Paulo, apresentam o trabalho cujo título é "Variação terminológica TradTerm, São Paulo, v.36, setembro/2020, p. 1-5 www.revistas.usp.br/tradterm 
denominativa no universo da cana-de-açúcar". O artigo apresenta os resultados preliminares de um estudo sobre a variação terminológica no universo da cana-de-açúcar no Brasil. O estudo toma como pressuposto teóricometodológico, sobretudo, a Teoria Comunicativa da Terminologia (CABRÉ, 1999, 2003) e o modelo teórico da variação terminológica de Freixa (2002, 2013), que apresenta seis causas para o fenômeno. A partir desses pressupostos, o estudo utiliza-se de um corpus com características diversificadas: textos orais produzidos por especialistas com alto grau de especialização, atuando em diferentes contextos comunicativos, como entrevistas televisionadas, palestras e aulas; textos escritos de diferentes gêneros, também elaborados por especialistas, como artigos científicos, apostilas de cursos de Agronomia, relatórios técnicos, sites do setor sucroalcooleiro, teses e dissertações. A pesquisa cruza diferentes fatores de variação e tenta apresentar os mais relevantes para a variação terminológica denominativa.

Ficam aqui nossos agradecimentos aos autores e pareceristas, aos esforços da nossa monitora Luiza Lotufo, no preparo do material, e a Sandra de Albuquerque Cunha, secretária do CITRAT. Convidamos os leitores a apreciar as publicações deste número da TradTerm desejando-lhes uma excelente e proveitosa leitura. 